\title{
THE IMPACT OF FOREIGN DIRECT INVESTMENTS ON BALANCE OF PAYMENT TRENDS IN MONTENEGRO
}

\author{
Zdravko Tomic ${ }^{1}$
}

\begin{abstract}
This paper examines the impact of foreign direct investments (FDI) inflow on balance of payment trends of Montenegro in the pre-crisis and post-crisis period. The motivation of this paper is based on the strong effect of previous FDI inflow on current account balance of payment trends. The main contribution of the paper is reflected in the identification of effects of the foreign investment process on the current account balance of payment trends. The results of the paper will show that the foreign investment process has led to deterioration of the balance of payment imbalance. The paper also presents the necessary measures that should be undertaken in order to gradually decrease the long-standing deficit in the goods account, as the main cause of external imbalance.
\end{abstract}

Keywords: FDI, balance of payment, current account balance of payment, exports.

\section{INTRODUCTION}

This paper examines the impact of FDI inflow on balance of payment trends of Montenegro in the pre-crisis and post-crisis period.

The current account balance shows a country's inflows and outflows arising from trade in goods, services, income and current transfers between residents and non-residents, i.e., on the occurrence of obligations to and claims on abroad

\footnotetext{
${ }^{1}$ GS1 Montenegro, Podgorica

DOI: 10.17932/EJOSS.2021.023/ejoss_v01i1006
} 
arising from the aforesaid transactions. The current account balance does not represent an economic policy variable such as, for example, money in circulation, but it is one of economic policy objectives like the inflation rate or a GDP level. Movements in the current account represent important sources of information for economic policy creators and they are also the reflection of monetary policy ${ }^{2}$.

Apart from the current account, the balance of payments also includes its other part: the capital and financial accounts, which explain how the current account is financed (in case of a deficit) or where the current account surplus funds are invested (in case of a surplus). The main components of the capital account are capital transfers and acquisition/sale of non-produced, non-financial assets. The financial account covers all financial categories classified in accordance with the investment type or functional classification (direct investment, portfolio investment, other investment, reserve assets). In cases when there is a current account surplus, the capital and financial account balance will be negative (for the purpose of balancing) and will show us where such current account surplus funds have been used (whether the country's foreign exchange reserves have been increased, or the scope of investments abroad and foreign lending has been increased or if there has been an increase of funds in so-called foreign exchange accounts).

Usually, the current account determines the movements in the overall balance of payments account, but this has started to change recently. The rapid development of the financial market and the emergence of a multitude of new financial instruments have led to a high supply of foreign capital in the form of

${ }^{2}$ Central Bank of Montenegro (2008), Sustainability Analysis of the Current Account Deficit of Montenegro, Podgorica. 
direct and portfolio investments and loans. All this - especially in the case of Montenegro - has had direct consequences for all current account items (goods, services, factor income and transfers).

\section{Effects of FDI on the balance of payments}

When assessing the impact of FDI on the balance of payments, it is necessary to take into consideration the impact of FDI on the country's imports and exports. It is well known that FDI usually finance the imports of equipment, machinery and missing raw materials, and thus influence the deterioration of the current balance of countries in transition. Negative effects on the current balance are especially prominent if the investments are oriented towards production for the domestic market (even more so if the aim of the FDI is the circumvention of customs duties). However, if such investments imply the subsequent substitution of import inputs with domestic products (through the establishment of stronger ties with domestic producers) or if they are export-oriented (along with better exploitation of existing resources in the host country), then FDI can contribute to a decrease in the trade deficit and their effect on the current balance can be positive.

The inflow of FDI is simultaneously a substitute for the country's foreign borrowing for the purpose of covering the current account deficit. Since borrowing implies the fixed repayment of the principal and interest in proportion with the interest rate - whereas the income from FDIs depends on their profitability - FDIs are the preferable way of financing the balance of payments current account imbalance. As long as the net inflow of FDIs is higher than the outflow of income on the basis of direct investments, FDIs have a positive impact on the domestic balance of payments. Having in mind the importance of increasing the value of goods and services exports, both for the trade deficit decrease and for more favourable values of some indicators of 
external solvency and liquidity, export-oriented FDIs manifest stronger overall effects on the balance of payments. The most favourable type of capital inflow from the perspective of the balance of payments are greenfield investments, especially those investments directed towards the construction of production capacities which produce exchangeable products. In addition, greenfield investments offer better possibilities for the transfer of foreign technology to the domestic economy and pave the way for advanced technology spillovers in other segments of the domestic economy.

Beside the import growth, another negative effect of FDIs on the host country's balance of payments is the repatriation of profits. FDIs are undertaken in order to generate a certain profit, which is then reinvested or transferred to the home country. The repatriation of profits represents an FDI outflow, which means: the higher the transfer of profits, the lower the net FDIs which serve to cover the current balance deficit. However, the transfer of profits can only happen if the respective subsidiary operates profitably, meaning that FDIs, regardless of the repatriation of profits, are preferable to foreign loans which must be repaid irrespective of the profitability of their use.

For the purpose of a more comprehensive and more complete understanding of the effects of FDIs on the balance of payments, it is necessary to consider the movements of direct investment income. The category of direct investment income is registered in the current balance primary income account, whereas FDI flows are recorded in the financial account. Therefore, the comparison between these two categories can serve for the assessment of the financial impact of FDIs on the balance of payments, i.e. if the FDI net income is deducted from the FDI net inflows, the result is a balance which can serve as the basis when reaching a conclusion on the effects of FDIs on the balance of payments. The primary income account includes reinvested earnings, in the category of equity (or more precisely as an item of investment income), in 
accordance with IMF's methodology. However, reinvested earnings are also recorded in the balance of payments financial account in the same amount, so the impact of this category on the balance of payments is neutral ${ }^{3}$. Still, in cases when the current account balance is negative, when reinvested earnings are recorded in the primary income account, the negative current account balance is increased. In such cases, caution should be exercised when assessing whether a specific amount of the current account deficit is sustainable or not. In fact, it may seem paradoxical that reinvestment increases the current account deficit, whereas in reality it can imply the purchase of domestic inputs for the extension of production, which does not require foreign exchange financing ${ }^{4}$.

The above leads to the conclusion that FDI have a stabilising effect on the balance of payments when the FDI net inflows are higher than the outflows of their income in the balance of payments primary income account. As long as this balance is positive, FDIs will be improving the balance of payments. However, with the ever-increasing FDI funds in the domestic economy, it can be expected that the outflow of income which they generate will grow in the long term, with a real chance that this outflow will surpass the FDI net inflow at some point. That is the moment when FDIs start to worsen the balance of payments.

${ }^{3}$ The primary income account shows the overall profit from FDIs, which includes reinvested earnings. Reinvested earnings are in their entirety included in the balance of payments financial account as well. These are in fact retained savings of foreign investors in the country, which are transformed into investments. Reinvested earnings can also be negative in some cases, e.g. if a company operates with losses or if the paid dividends are higher than the earnings. Negative reinvested earnings are treated as withdrawal of capital.

${ }^{4}$ Kovačević R. (2016), Foreign Direct Investment (FDI) as a factor of stabilization Serbia's balance of payments, Discussion paper, The Faculty of Economics University of Belgrade. 
In order to get a more complete grasp of the financial flows generated by FDIs, it is certainly recommended to use the results of the research carried out by Brada and Tomšík (2003). In their famous and highly quoted paper, Brada and Tomšík (2003) point out three financial stages through which FDIs go. The first stage implies the investment in the host country with the aim of establishing a foreign company's subsidiary. This stage, according to said authors' findings, is characterised by operating losses due to initial difficulties, which may arise during the launch of operations. It is the opinion of these authors that this stage is especially prominent in the case of green field investments, where it can be longer, while on the other hand it can be shorter in the case of an acquisition, because an acquired firm can quickly become profitable. After the initial difficulties are overcome, the subsidiary should enter the zone of profitable operations, but at this stage, the company reinvests the majority of its earnings for the purpose of expanding operations or eliminating structural problems. As opposed to the previous stage - where the focus is on financing with the help of intracompany loans - at the second development stage, the company demonstrates a growing reliance on financing sources in the host country. At the third stage, the company enters the 'maturity' zone, and the profit margins and market share in the host country are stabilised at this financial stage, which is why the parent company can decide to withdraw a major part of the profits from the subsidiary in the form of dividends and invest these funds in other places in the world which offer a better yield. Reinvested earnings become smaller and smaller at this stage. That moment can be delayed by stimulating foreign investors to reinvest the generated profits and dividends in the domestic economy. At this stage, companies usually don't need any explicit help from the parent company, and instead they rather rely on the domestic banking system as the source of financing. 


\section{The movement of FDI flows and Montenegro's current account deficit}

Montenegro's current account deficit in the years of strong economic growth and investment boom was the highest in Europe (in \% of GDP for the period 2005-2008). The main source of financing the current account deficit of Montenegro were FDI. According to the IMF, the current account deficit could be considered a balanced response of a system to a large inflow of foreign private capital and a high credit growth rate. The annual amounts of FDI in Montenegro were relatively moderate by 2005 , primarily due to the volatile macroeconomic and political situation. The opening of the economy, macroeconomic stability, stabilization of the political situation, the banking sector recovery that resulted in the arrival of strong banks, increase in salaries and banking loans, creation of business-friendly environment for foreign investors and large FDI inflows, a higher credit rating of the country, and growth in construction investments are some of the factors which directly influenced an increase in domestic demand and the import of goods which resulted in the high current account deficit. The Montenegrin economy could not meet growing demand for goods arising from the increased purchasing power and greater investments. This induced exceptionally high growth in visible imports which was followed by much lesser visible exports.

The year-on-year FDI inflow in 2005 increased by 7.5 times and being even 9 times larger than in 2003. The uptrend in FDI inflow continued in 2006 and 2007 when EUR 644.3 million and EUR 1,007.7 million of gross FDI were received, respectively ${ }^{5}$. Strong FDI inflow during 2005 induced a strong growth in imports in the second quarter of 2006, when it increased from EUR 230 million, as was the average from the previous nine quarters (as of 2004), to over EUR 400 million. During 2005, net FDI investments completely covered

\footnotetext{
${ }^{5}$ Central Bank of Montenegro (2008), Sustainability Analysis of the Current Account Deficit of Montenegro, Podgorica.
} 
The Impact of Foreign Direct Investments on Balance of Payment Trends in Montenegro

the current account deficit, while in the following year this coverage was $88 \%$. The current account deficit in 2007 amounted to EUR 1,058.7 million, compared to 2006 , this was an $89.7 \%$ growth. Net FDI inflow covered only $52 \%$ of the current account deficit in $2007^{6}$. The financing of the current account deficit from FDI inflow is good from the aspect of capital maturity (there is neither an increase in the external debt nor there is any tendency towards rapid capital withdrawal), but the problem is the structure of direct investments by activities. In 2007, 51\% were real estate investments, $37.5 \%$ was invested in banks and companies, and the remaining was in the form of intercompany debt (investments between associate companies). The aforesaid leads to a conclusion that the existing FDI structure is not good.

There is a great difference between Montenegro's spending (investments) and that what it is able to produce ${ }^{7}$.

\section{Graph no. 1: FDI inflows and the current account deficit (\% of GDP)}

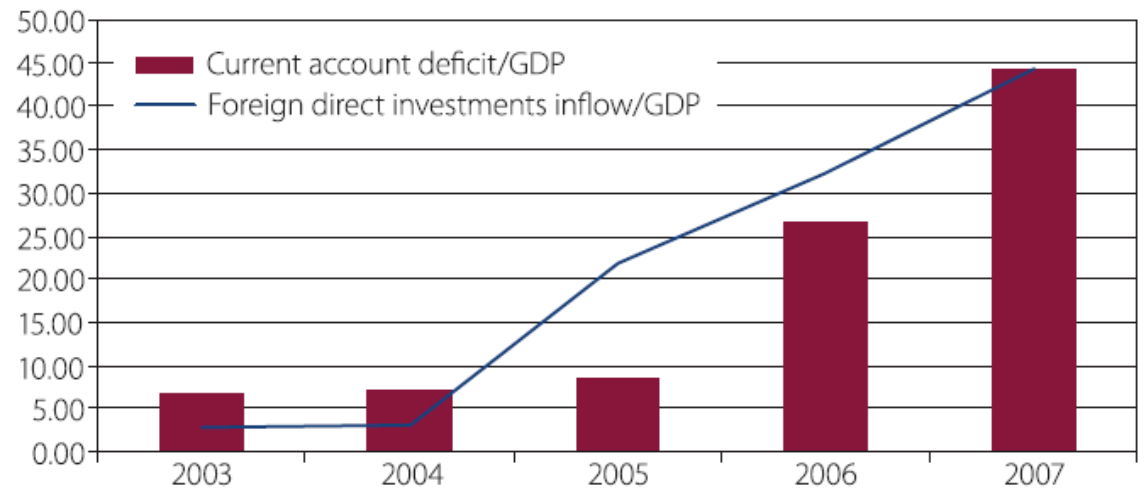

Source: $C B M$

Therefore, FDI had a direct impact on the increase of the deficit of the balance of payment current account. On one hand, this is a result of the accelerated

${ }^{6}$ Central Bank of Montenegro (2008), Foreign Direct Investments as a Driver of Economic Development of Montenegro, Podgorica.

${ }^{7}$ Central Bank of Montenegro (2008), Sustainability Analysis of the Current Account Deficit of Montenegro, Podgorica. 
growth, because the foreign investors have made additional investments in the companies that they have purchased in order to increase their competitiveness. As Montenegro's economy did not produce most of the material necessary for the investment process, foreign investors imported everything they needed: construction material, machinery and other equipment, raw material, furnishings and the like. Second flow was due to the fact that many individuals have increased their living standards thanks to the sale of real estate. This has resulted in the large growth of the car sales, furniture sales, etc. These are all permanent consumption goods that are not produced in Montenegro, therefore the result was the increase of imports. The above can be confirmed by regression analysis. The initial assumption of the analysis is that FDI in the period of strong economic growth (2005-2007.) directly affected on the growth of the current account deficit. Movements of the relationships between the FDI inflow and the increase of the current account deficit is presented in the following graph: 
Graph no. 2: Regression between FDI and the current account deficit (20052007.)

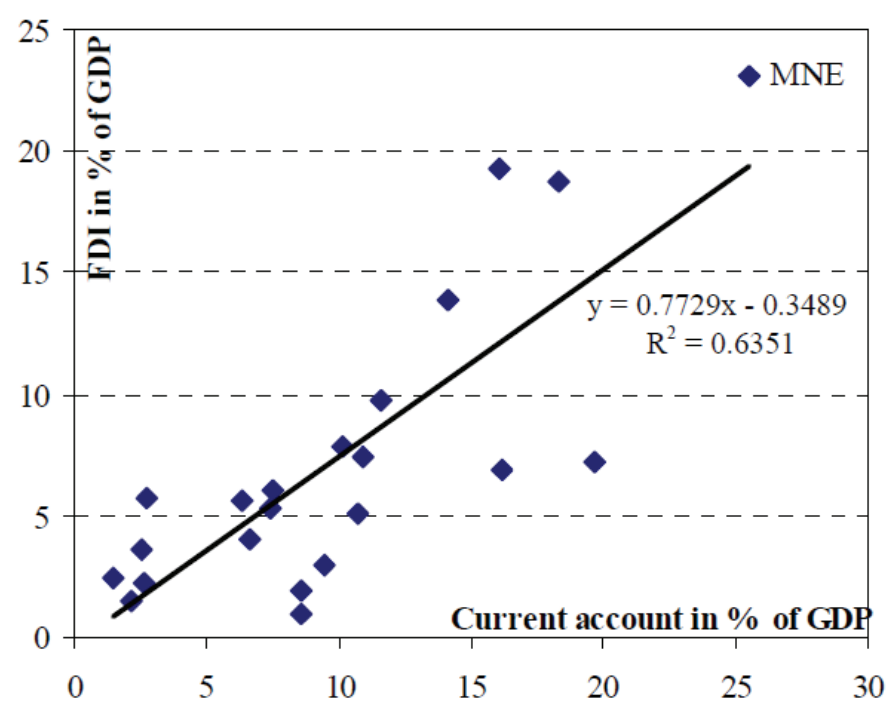

Source: World Economic Outlook

As the inflow of FDI funds started to increase so did their outflow. The purchase of land, real property construction and then its sale with the price difference, showed as a profitable business, but this time the incentive for further export growth is foreign borrowing. In addition, residents started to directly invest abroad. However, the secondary effects are positive and reflect in an increase in tourism revenues and declines in interest rates, unemployment, expenses for telecommunications etc.

The balance of payments data of Montenegro show that in recent years (20112018) there is a gradual decrease in the current account deficit compared to the pre-crisis period (2005-2008). The decreasing trend in the current account deficit characterized the period since the crisis began, and largely a result of the crisis adjustment of the economy and reduction in aggregate demand. Due to the reduction in capital inflows, a part of the current account deficit has self- 
correcting effects, that is, the cessation of FDI inflow will lead to a substantial reduction in imports. However, despite a reduction external imbalance, it is evident that the foreign trade deficit is significantly high and constantly present.

Although the current account deficit is to a large extent the consequence of the accelerated growth, the reason for concern is the fact that it is less covered by FDI, while the private external debt increases.

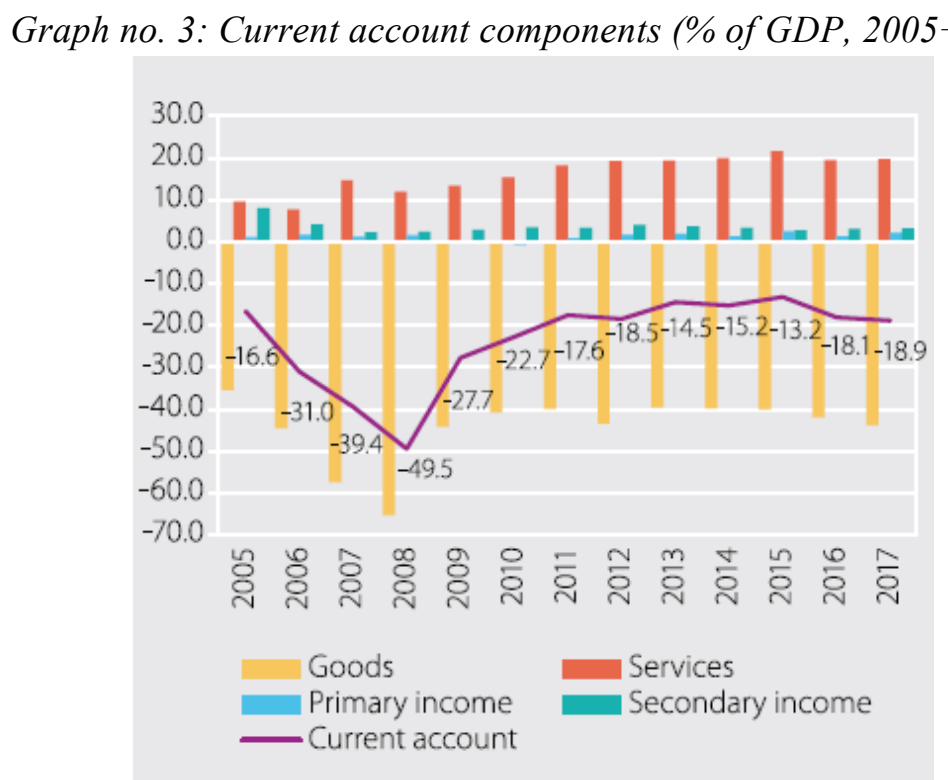

Source: CBM, Monstat

The deficit of the current account balance amounted to 799.3 million euros in 2017 or $18.9 \%$ of GDP, which is a significant reduction in view of the high values achieved in the pre-crisis years (2005-2008), where it is only in 2008 achieved the deficit of the current account of the 50.6\% of GDP. The goods account deficit widening was driven by an increase in the visible imports, to an extent, such a rise in the goods deficit was to be expected in view of the implementation of significant infrastructure projects. As in the previous years, the 2017 deficit was primarily funded by FDI and their net inflow of 474.3 million euros or $11.2 \%$ of GDP. Also, historically, constant current account 
deficit was also funded by foreign portfolio investments and other foreign investments with pronounced debt features. Moreover, debt instruments (intercompany debt) also accounted for a portion of FDI so the "other side“ of current account deficit was in fact the accumulation of external debt of Montenegro of all resident sectors, the government included, although the external government debt was the most prominent ${ }^{8}$.

\section{Sustainability of the current account deficit}

A current account deficit that has accumulated over the years requires continuous funding sources: through net FDI inflows, portfolio investments, credit transactions or through reducing a country's foreign exchange reserves. However, the main question is what does the term "sustainability" actually imply? The opinion of many economists and economic policy creators regarding a country's external imbalance has changed significantly over the last decades. Today there is no common, generally accepted stance on the current account level that could be considered unsustainable or about the actual effects of a high current account deficit on other macroeconomic indicators. For many years, the IMF`s and other international financial institutions` standpoint on the current account level that is considered unsustainable is that which exceeds $5 \%$ of GDP. However, there are examples of many countries that have succeeded in sustaining and financing the current account deficit higher than the aforesaid threshold for many years and then turning it into a surplus; however, there are also many countries that ran a low current account deficit but could not avoid the balance of payments crisis (Mexico, Chile). All this has led to the abandoning of such a strictly established criterion. The advocates of the thesis that "the balance of payments crisis is largely a politically charged phrase"

\footnotetext{
${ }^{8}$ Central Bank of Montenegro (2018), Financial System Stability Report for 2017, Podgorica.
} 
point exactly to the countries such as the USA, Spain, Slovakia, etc. They claim that a country can run the current account deficit for years, yet the economy will not suffer if the deficit is used for private financing of investments. On the other hand, the budgetary deficit can cause default in foreign obligations, that is, actually induce the balance of payments crisis. However, the opinion that the current account deficit is not important if it is a result of the private sector deficit (Lawson doctrine) ${ }^{9}$ was discredited by the Asian financial crisis which occurred during 1997 and 1998. The crisis occurred due to a large external exposure of the private sector regardless of the balanced budget ${ }^{10}$.

If we begin with the fact that each deficit has to be financed, that is, should have the sources of financing, then it could be said that the current account deficit is sustainable to the degree and within time limits the creditors consider sustainable. The current account deficit is sustainable if the continuation of the country's current economic policy and/or the behavior of the private sector and possible external shocks will not call for the introduction of significant changes in the economic policy nor induce the balance of payment crisis. As long as financial markets have confidence that the debtor country will duly service its obligations, the debtor crisis will not occur. In the previous period the main source of financing the current account deficit of Montenegro were FDI.

Therefore, it could be stated that there is no unique criterion for the assessment of the current account deficit sustainability which could be applied to all countries. When performing an assessment one should take into consideration specific characteristics of each country and other macroeconomic indicators

\footnotetext{
${ }^{9}$ According to the Lawson doctrine, named after Nigel Lawson, as long as the current account balance reflects the private sector savnigs-investment decisions, there are no disturbances and expectations are rational, then there is no reason for a government to intervene.

${ }^{10}$ Central Bank of Montenegro (2008), Sustainability Analysis of the Current Account Deficit of Montenegro, Podgorica.
} 
The Impact of Foreign Direct Investments on Balance of Payment Trends in Montenegro

(inflation rate, GDP growth rate etc.), monitor the current account trends, the structure of imported goods (consumer goods or investment goods), the capitalfinancial account situation (foreign direct and portfolio investments, loans and their maturity structure and purpose).

As for Montenegro, the current account deficit /GDP growth ratio can be taken as the criterion for the sustainability of the current account deficit. If the deficit increase is higher than GDP growth over long-term, then the current account deficit will be unsustainable. This indicator should not be observed in shortterm, because a short-term deficit can indicate that it has been financed by investment which will influence GDP growth in the forthcoming period. In the eurosation conditions, the current account deficit entails less risk than in countries having their own currency, but the options for its elimination are narrowed in the absence of exchange rate policy. In a euroised and highlyopened economy with low transaction costs, local and foreign products become substitutes and households easily turn to imported products. Therefore, the current account deficit over a longer period of time, when dried up funding sources and the time comes to repay the loan, it can lead to a decrease in the money supply, which can have the effect of recession on the economy.

There is still a significant inflow of FDI provide enough foreign accumulation for financing the current account deficit, but it is on the other side of one of the factors creating the deficit. Long-term deficits in the account of goods represent the main causes for external imbalances. Relatively low values of export, combined with higher values of import represent the reason for the deficit in the visible trade. In addition to this, export is dominated by a small number of lowprocessed manufacturing goods which include low levels of added value and generate fewer benefits from export. In order to change the existing situation, it is necessary to change the export structure and reduce import dependence. What is also required is a better structure as well as greater levels of export that is 
based on technology-intensive products and innovations. The structure of import is also unfavourable. It would be significant to make the import structure more oriented towards equipment, machinery and technologically advanced products that would generate new business processes and new products for export instead of towards goods for personal consumption.

Thus, strengthening and diversification of exports while increasing productivity and competitiveness are the imperatives of the Montenegrin economy development in the future. Montenegro has comparative advantages and great potential for export growth in sectors such as tourism, energy and agriculture.

Each country has limited capabilities to absorb FDI inflow, but it is certain that they are still not used in Montenegro, meaning that Montenegro may count on large FDI inflows in the medium-term period of three to five years. Thus, it will not be possible to significantly reduce the current account deficit. On the other hand, initial investments in the construction of roads (highway Bar-Boljare), power capacities or the implementation of some other large announced projects will certainly lead to growth in imports. This is the development component of the deficit, which bring positive effects in the long-term. In addition, as a result of large FDI inflow in the upcoming period, we should expect larger export revenues, which are now obvious in tourism. This means that corrective measures do not have to be undertaken when this development is in question. Of course, it would be of exceptional importance to influence the change of the FDI structure, that is, their redirection from real estate to other fields.

Still, it should be kept in mind that FDI net inflows represent an alternative source of deficit funding, which mitigates the burden of foreign debt. But, with this type of capital inflows, attention must be paid to the possibility of the repatriation of profits and possible withdrawal of capital, which would make the funding of the achieved current account deficit more difficult. 
Among concrete measures for reducing the foreign trade deficit - which is the main cause for the Montenegrin balance of payments current account deficit we should point out the increase/stimulation of exports and substitution of imports, as follows:

- Reducing the import dependency by increasing the domestic production in sectors where Montenegro has comparative advantages, such as: agriculture and food industry (production and processing of food for the needs of both the country's own citizens and tourists during the tourism season) and energy industry (construction of new production capacities, where natural potential exists),

- Increase of exports and better exploitation of available industrial capacities (steel, aluminium, bauxite, timber, etc.),

- Increase of tourism-generated revenues and better exploitation of the natural potential.

Having in mind the importance of increasing the value of goods and services exports for the reduction of the trade deficit, export-oriented FDIs exhibit stronger overall effects on the balance of payments. Thereby, FDIs contribute to the stabilisation of the balance of payments, especially those investments which are aimed at the construction of production capacities which produce exchangeable products. To that end, it is very important to apply various economic policy measures to direct FDIs towards the sectors which can become the backbone of exports in the upcoming period.

\section{The current account deficit of Western Balkan countries}

The inflows of foreign capital to the Western Balkan countries before the outbreak of the global financial crisis in 2008. supported the growth of domestic demand, which was partially satisfied by imports (Wyplosz, 2013). This conditioned the growth of the current account deficit. The liberalization of 
foreign trade has facilitated imports and contributed to the growth of the trade deficit. The capital inflows into these countries have been increased as a result of the low interest rates as well as the increased amounts of available global liquidity. Strong domestic demand has generated high rates of economic growth. However, a significant increase in prices and wages, primarily due to the expected convergence of income, weakened the sector of tradable goods in these countries. The result has been a high increase in external debt, which could adversely affect debt servicing capacities, and weaken the competitiveness of the economy. The mitigating circumstance for these countries is the significant net inflow of FDI, as an important channel of financing the current account deficit. The countries of the region have made adjustments after the outbreak of the global economic and financial crisis, with the accompanying reduction in the current account deficit. However, the main direction for financing a sustainable current account deficit is to increase export competitiveness and export revenues. In this way, the trade deficit would be reduced, and the current account deficit may become sustainable.

The current account deficit of Western Balkan countries had an oscillatory dynamics in the period from 2000 to 2015. All Western Balkan countries have recorded a persistent current account deficit since 2001. Its highest value was achieved in the crisis year 2008 (extreme value deficit is achieved in Montenegro). In the period after 2008 there was a reduction of the deficit in the range of 0 to $20 \%$ of GDP. Borrowing abroad is the main source of financing the deficit in the Western Balkan countries. In this way, they bridge the gap between lower domestic savings and larger investments. If foreign funds are not used to build productive capacity, the country's ability to repay debts will be diminished, and insolvency is also inevitable. This raises the question of sustainability of the current account deficit. Problems can also arise due to sudden withdrawals of capital, in which case the countries would have to make 
The Impact of Foreign Direct Investments on Balance of Payment Trends in Montenegro

a current account surplus which will be allocated for debt repayment. A steady current account deficit can increase the economic vulnerability of these countries $^{11}$.

Graph no. 4: Current account balance in Western Balkan countries (\% of GDP)

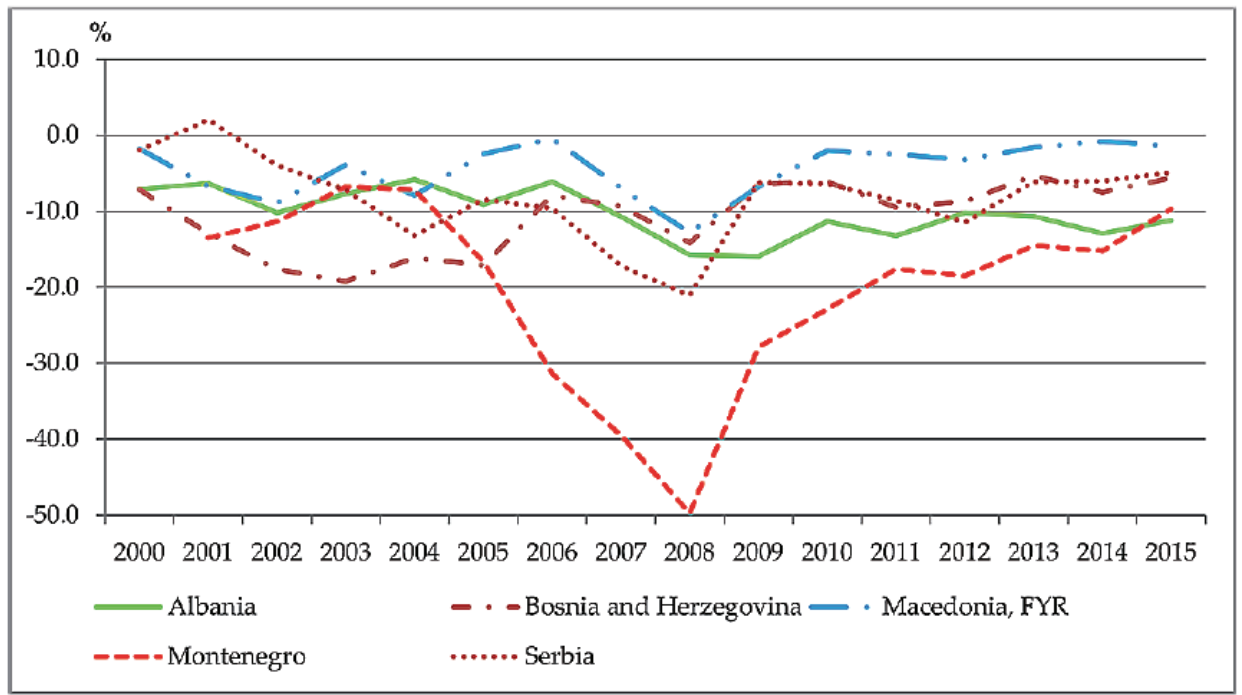

Source: IMF, World Economic Outlook Database (October 2016).

Some authors believe that the boom in domestic demand in the period before the 2008 was a more important cause of the current account deficit, than it was the loss of price competitiveness (Wyplosz, 2013).

Before the onset of the 2008 crisis the current account deficit was significantly supported by inflows of foreign capital. The decline of the interest rates on international capital markets facilitated borrowing under favorable terms, which accelerated the accumulation of foreign debt and the current account deficit increase. The increase in debt has not been accompanied by the increase in capacity to service this debt. The appreciation of the national currency, spurred

\footnotetext{
${ }^{11}$ Kovačević R. (2017), Financing the current account deficit in Southeastern European countries, Bankarstvo, 2017, Vol. 46, Issue 3, Belgrade.
} 
by the large inflows of foreign capital, has led to the deteriorated export competitiveness. After the outbreak of the crisis, all countries recorded a reduction in their current account deficits, primarily due to the weakening of economic activity and the reduction of imports. The liberalization of foreign trade has had not only a positive impact on the competitiveness of the economy and the strengthening of competition on the domestic market, but has also opened up the channel for increasing the current account deficit. In this way, the increasing openness of the economy imposed the issue of sustainability of the growing current account deficit. Graph 5 shows the tendencies of the openness of the economy of the Western Balkan countries.

\section{Graph no. 5: Trade openness of Western Balkan countries}

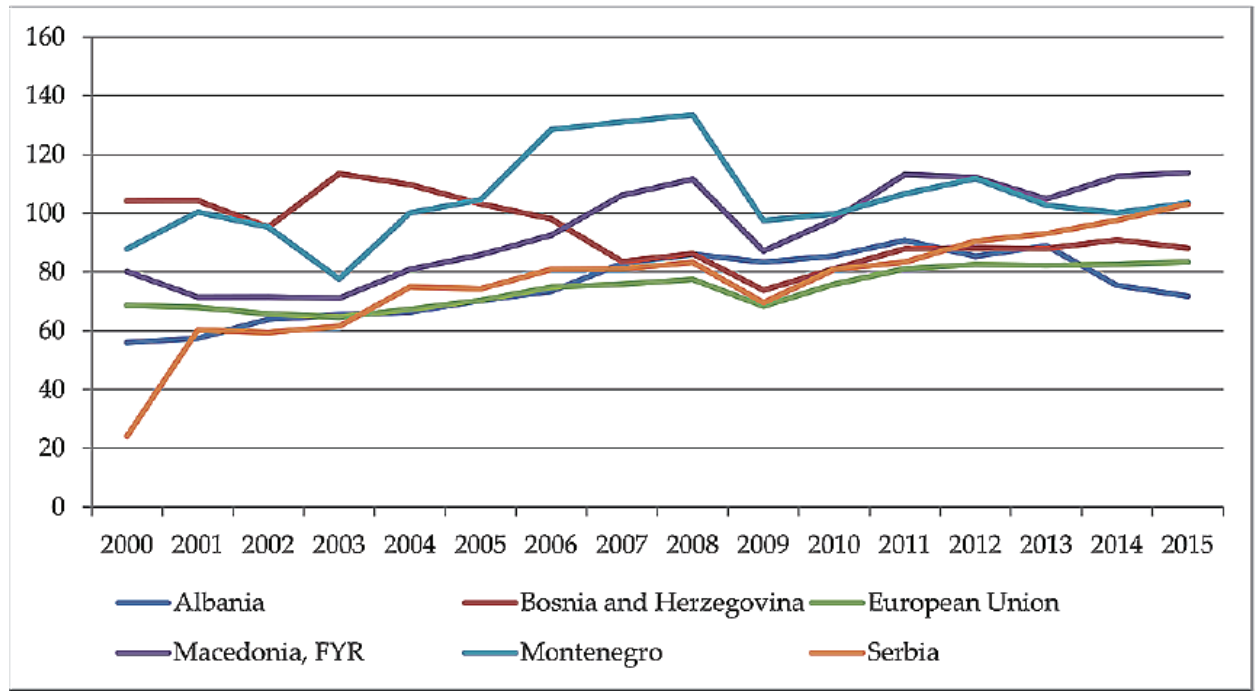

Source: The World Bank, http://data.worldbank.org/indicator/NE.EXP.GNFS.

In most of the Western Balkan countries, the exports are dominated by labor and resource intensive products, or products of lower technological intensity. Unlike the Western Balkan countries, the EU countries have a high share of technologically intensive exports, and their specialization goes in that direction. With this picture, the Western Balkan countries will face the moment of joining the EU. The dynamic investment in infrastructure in the region, with a 
prominent role of the Chinese investments, is becoming an important factor in raising exports to a higher level. The well-developed transport infrastructure is an important prerequisite for the competitiveness of the region and its economic development.

Long neglected, this infrastructure in many cases is a limiting factor in the increasing of exports (Sanfey et al., 2016, p. 27). A stronger interconnection among the Western Balkan countries within the CEFTA agreement, as well as the signed EU Stabilization and Association Agreements, open the space for increasing the share of their export of goods and services in GDP.

The expansion of the current account deficit, stimulated by the acceleration of economic activity in the period before the outbreak of the global economic crisis in 2008, was largely financed by FDI inflows as well as foreign loans. However, a significant portion of this inflow was directed to the sectors that produce for the domestic market. As a result, these funds did not significantly affect the productivity growth or the expansion of production for export purposes. Along with the current account deficit increase, the surplus of the financial account in the Western Balkan countries has grown. This generated the tendency for growth of foreign exchange reserves, which doubled in comparison to the usual amounts. For most Western Balkan countries, FDI is the main source of external financing (The World Bank, 2016 p. 9).

In most countries in the region, there has been an increase in remittances inflows from abroad. This type of foreign exchange inflow is an important source for financing a part of the trade deficit. This is the reason to create incentive measures that would contribute to increasing the inflow of these funds through investment motivation.

Therefore, it is important to get FDIs largely directed into the export sector and the strategy of economic growth should be based on exports. However, the 
increase in interest rates on the international capital market implies an increase in the burden of debt servicing and less profits in the corporate sector, which can slow down the growth of net FDI inflows. In that case, the alternative way for financing the current account deficit is the additional external debt. However, this option has already been exhausted for some countries because their external debt is close to $80 \%$ of their GDP, the boundary when overindebtedness becomes unavoidable. These countries cannot afford this luxury, because the transition to a state over indebtedness exacerbates the conditions of external borrowing, and an increasing part of the foreign exchange inflows is separated for the purpose of external debt servicing. In this situation, the countries should undertake a structural adjustment that would imply a further reduction of the current account deficit and bring it back within the borders that are sustainable from the point of view of available resources for its financing.

\section{CONCLUSION}

Montenegro's current account deficit in the years of strong economic growth and investment boom was the highest in Europe (in \% of GDP). The main source of financing the current account deficit of Montenegro were FDI. According to the IMF, the current account deficit could be considered a balanced response of a system to a large inflow of foreign private capital and a high credit growth rate. The balance of payments data of Montenegro show that in recent years there is a gradual decrease in the current account deficit compared to the pre-crisis period. The decreasing trend in the current account deficit characterized the period since the crisis began, and largely a result of the crisis adjustment of the economy and reduction in aggregate demand. However, despite a reduction external imbalance, it is evident that the foreign trade deficit is significantly high and constantly present. 
There is still a significant inflow of FDI provide enough foreign accumulation for financing the current account deficit, but it is on the other side of one of the factors creating the deficit. Long-term deficits in the account of goods represent the main causes for external imbalances. Relatively low values of export, combined with higher values of import represent the reason for the deficit in the visible trade.

Therefore, strengthening and diversification of exports while increasing productivity and competitiveness are the imperatives of the Montenegrin economy development in the future. Montenegro has comparative advantages and great potential for export growth in sectors such as tourism, energy and agriculture.

\section{REFERENCES}

[1.] Brada, J.C. and V. Tomšik (2003), Foreign direct investment and perceptions of vulnerability to foreign exchange crises: Evidence from transition economies, ZEI working paper, No. 543.

[2.] Canton, E. and Solera, I. (2016), Greenfield Foreign Direct Investment and Structural Reforms in Europe: What Factors Determine Investments?, Discussion paper 033, European Commission, Luxembourg.

[3.] Central Bank of Montenegro (2018), Annual Macroeconomic Report of the CBM for 2017, Podgorica.

[4.] Central Bank of Montenegro (2018), Financial System Stability Report for 2017, Podgorica.

[5.] Central Bank of Montenegro (2008), FDI as a Driver of Economic Development of Montenegro, Podgorica.

[6.] Central Bank of Montenegro (2008), Sustainability Analysis of the Current Account Deficit of Montenegro, Podgorica. 
[7.] Cesaroni, T., and De Sant, R. (2015), Current account "Core-periphery dualism" in the EMU, LEQS Paper No. 90/2015. London: LSE.

[8.] Drahokoupil, J. and B. Galgóczi (2015), Foreign direct investment in eastern and southern European countries: still an engine of growth?, in: B. Galgóczi, J. Drahokoupil and M. Bernaciak (Eds.), Foreign investment in eastern and southern Europe after 2008: Still a lever of growth?, ETUI aisbl, Brussels.

[9.] Gabrisch, H. (2015), Net Capital Flows to and Real Exchange Rate of Western Balkan Countries, Economic Annals, Vol. LX, No. 205 / AprilJune, DOI:10.2298/EKA1505031G.

[10.] Hanousek J., Kočenda, E. \& Maurel, M. (2011). Direct and indirect effects of FDI in emerging European markets: A survey and meta-analysis. Economic Systems, 35 (3), pp. 301-322.

[11.] Kovačević R. (2017), Financing the current account deficit in Southeastern European countries, Bankarstvo, 2017, Vol. 46, Issue 3, Belgrade.

[12.] Kovačević R. (2016), Foreign Direct Investment (FDI) as a factor of stabilization Serbia's balance of payments, Discussion paper, The Faculty of Economics University of Belgrade.

[13.] Mencinger, J., (2016), Direct and indirect effects of FDI on current account,http://www.raumplanung.tudortmund.de/irpud/presom/fileadmin/d ocs/presom/external/13th_workshop / Mencinger. pdf Accessed on 12th October 2016.

[14.] Milessi-Ferretti, G.M. and A. Razin (1996), Current Account Sustainability, Princeton Studies in International Finance, No. 81 (October), Princeton, New Jersey. 
[15.] Moura, R. and Forte, R. (2010). The effects of foreign direct investment on the host country economic growth-theory and empirical evidence, No. 390, Universidade do Porto, Faculdade de Economia do Porto.

[16.] Sanfey et al. (2016), How the Western Balkans can catch up, EBRD Working paper No. 186. London: EBRD.

[17.] UNCTAD (2017), World Investment Report 2017: Investment and Digital Economy. Geneva: UN.

[18.] World Bank Group (2016), South East Europe Regular Economic Report No.10: Resilient Growth Amid Rising Risks, Washington, DC: The World Bank.

[19.] Wyplosz, C. (2013), Europe's Quest for Fiscal Discipline, European Economy Economic Papers 498. Brussels: European Commission. 